This is the Accepted Version of the following article:

Mukherjee, Jenia; Morera, Raphaël; Guerrin, Joana; Véron, René. Histories of urban deltascapes: A comparison of Arles and Kolkata. Global Environment, Volume 14, Number 3, September 2021, pp. 505-534.

Publisher: White Horse Press

The definitive publisher-authenticated version is available online:

https://doi.org/10.3197/ge.2021.140304

(C) White Horse Press 


\title{
Histories of urban deltascapes: A comparison of Arles and Kolkata
}

\begin{abstract}
Delta cities are exposed to cycles of fluvial risks that have been managed across space and time. Floods and flood mitigation in urban deltascapes are therefore dependent on territorial and historicised dynamics. This paper uses historical urban political ecology to unravel the changing interactions between biophysical and political-economic processes affecting urban deltascapes in particular periods from the sixteenth century onwards. We present two case studies: Arles (on the Rhône Delta, France) and Kolkata (on the Bengal Delta, India). Our empirical findings point to the influence of connected global processes and to similarities in historical trajectories. In particular, both case studies reveal state efforts to 'fix' the fluid deltascape originally managed by local institutions, altered flood vulnerabilities (in terms of frequency, intensity and space), and more recent initiatives of mediation between interest groups. Through this unexpected comparison, more generally, we aim to contribute to a (global) environmental history that is sensitive both to local specificities and complexities and to the influence of global processes.
\end{abstract}

\section{PROLOGUE}

June 10, 2016: We are in Lyon, France, standing on the embankment of the Rhône River Rhône has been etymologically associated with "to run, to roll". We reach Arles during the afternoon; our discussions with public environmental actors from Conservatoire du Littoral, Parc naturel régional de Camargue and CPIE, a local environment education association are fruitful. Representatives from CPIE Rhône join us on a visit of the Camargue Festival. The vast saline delta and marshland between the two arms of the Rhône, spreading like a fan from the city of Arles, bear testimony to its long history and culture. The 1859 sea dyke indicates the state's heavy reliance on its technological apparatus to protect the region from flooding. The river reflects efforts of severe straightening and embanking as part of flood control measures. The route from Lyon to Camargue through Arles validates the history of a series of interventions to tame the Rhône Valley and the delta.

February 2, 2017: It is a wintry morning and the Ganga river mouth appears misty. We discuss how Sagar, a place of Hindu pilgrimage at the confluence of the river and the sea, is 
shrouded in mythologies that encapsulate the essence of the deltascape. Long concrete embankments, dilapidated in some areas, makeshift houses and cyclone shelters in school premises point to the frequency of floods and environmental risks in the Sundarbans and the continued saga of human adjustments to hydrological extremes.

February 3, 2017: We have now moved northward from the delta and reached the vast watery world intermitted by lush green patches - the East Kolkata Wetlands (EKW), the lifeline of Kolkata. It is a long and hectic day, packed with interviews and informal on-site conversations. The vivid descriptions by irrigation officials, municipal engineers, fishers and bhery (fish-pond) owners, as well as our own visual immersion while crossing age-old elaborate technological arrangements, such as sluices, lock gates or pumping stations, confirm flood vulnerability of the city and its responses to risks since historical times.

\section{- Extracts from field diaries ${ }^{1}$}

Exposure to the Ganga and Rhône basins during an Indo-Swiss exchange program beguiled our group of European and Indian researchers into discovering both similarities and specificities that shape floodplains and urban deltascapes across varied geographies. The phenomenological encounters motivated us to critically interrogate "global" discourses on floods, disasters, vulnerability and resilience. Positioning global North and global South as binaries in disaster scholarship appeared problematic, in dire need to be reframed and reworked. The cross-cultural learning experience eventually laid the foundations for a team of researchers from Switzerland, France and India to engage in hydrosocial analysis of flood paradigms and management practices in the Rhône and Ganges basins. Archival and ethnographic explorations of the interaction of flood risks and human adjustments in these distinct yet comparable spatial and political settings have provided a means to reinvigorate (global) environmental history that is sensitive to "local" differences and complexities, yet conveys the "global" by mapping and accommodating together similar historical trajectories of change along varied geographical contexts.

\section{INTRODUCTION}

Environmental history and political ecology have convincingly demonstrated that floods are concurrently bio-physical, technological and social phenomena and that they are strongly

\footnotetext{
${ }^{1}$ Field entries (by Mukherjee) from the Indo-Swiss Scholars Exchange Grant (2015-2017) on Political Ecology of River: Indo-Swiss Exploration of Hydrosocial Dynamics in the Lower Stretch of the Ganges.
} 
shaped by territorial, political and historicized dynamics. South Asian water historians, ${ }^{2}$ for example, have contributed to an emerging delta and coastline scholarship by problematizing the solid-liquid binary and by proposing fluid epistemologies that capture multi-layered realities surrounding "deltascapes". ${ }^{3}$ In European environmental history, furthermore, floods have been conceptualised as a driver for institutional and political change. ${ }^{4}$ Historical anthropology, moreover, has explored "the interconnection of multi-directional narratives of flooding through the representation of the memories of inhabitants of wet landscapes in past and present." ${ }^{5}$ In general, social sciences frameworks confront the projection of disasters as "natural" - as it is often done by global agencies to legitimize state-led floodplain development and to prevent social discontent. ${ }^{6}$ More specifically, political ecology has contributed to an understanding of what is and what is not natural about floods by exploring power dynamics in resource allocation and risk production. ${ }^{7}$

Global apprehensions of, as well as anxieties about, climate (flood) risks in delta cities, where floods are frequent, have led to a series of policy recommendations to tackle multi-layered vulnerabilities of cities of the global South characterized by ecological crisis, demographic growth and financial constraints. International organizations, such as the United Nations Office for Disaster Risk Reduction, have developed globalist prescriptions - for example, in terms of success factors - to cope with risks through guided mitigation and adaptation measures. ${ }^{8}$ Shortcomings of such universal conceptualizations of disasters and of mitigation

2 J. Mukherjee, 'From hydrology to hydrosociality: Historiography of waters in India', in J. Caradonna (ed.), Routledge Handbook of the History of Sustainability (London: Routledge, 2018). J. Mukherjee and P. Ghosh, 'Fluid epistemologies: The social saga of sediments in Bengal', Ecology, Economy and Society - The INSEE Journal 3(2) (2020): 135-148.

${ }^{3}$ Inspired by the concept of landscapes used in urban political ecology (Swyngedouw, E. 2004. Social power and the urbanisation of water: Flows of power. Oxf ord: Oxford University Press), we use the term deltascape to describe the fluid and dynamic deltaic landscapes as they are shaped by material and institutional interventions and thus imbued with power relations.

${ }^{4}$ B. van Bavel, D. R. Curtis, J. Dijkman, M. Hannaford, M. de Keyzer, E. van Onacker and T. Soens, Disasters and History: The Vulnerability and Resilience of Past Societies (Cambridge: Cambridge University Press, 2020).

${ }^{5}$ F. Krause, J. Garde-Hansen and N. Whyte. 'Flood memories - media, narratives and remembrance of wet landscapes in England', Journal of Arts and Communities 4(1-2): 128-142.

6 T. Steinberg, Acts of God: The Unnatural History of Natural Disaster in America (Oxford: Oxford University Press, 2006).

7 F. Sultana, 'Living in hazardous waterscapes: Gendered vulnerabilities and experiences of floods and disasters', Environmental Hazards 9(1) (2010): 43-53. F. Lafaye de Micheaux, C. Kull and J. Mukherjee, 'When hydrosociality encounters sediments: Transformed lives and livelihoods in the lower basin of the Ganges River', Environment and Planning E 1(4) (2018): 641-663.

${ }^{8}$ H. Schofield and J. Twigg. Making Cities Sustainable and Resilient (Geneva: UNDRR). 
measures have been discussed for a long time. ${ }^{9}$ We attempt to show, moreover, that historical, comparative, in-depth empirical research can enrich this literature and offer additional insights that are necessary to challenge and complicate global perceptions and prescriptions for environmental risks such as floods. We will use detailed case studies of delta cities that traverse connected historical trajectories and that assemble "storylines" ${ }^{10}$ of dominant, repressed and obliterated accounts of historical coproduction of urban deltascapes as the vantage point to disrupt conventional narratives conferred by disaster studies.

For this purpose, we draw upon two historicized case studies of delta cities, Arles in France and Kolkata in India. The case studies draw conceptually upon the political ecology of floods, yet broadening the scope of this approach by a particular attention to the urban and to history. The proposed historical urban political ecology (HUPE) framework enables us to explore the changing interaction between biophysical dynamics and political processes affecting urban deltascapes in and across different historical periods. For example, historical analysis demonstrates that both deltascapes have been materially and institutionally transformed with similar goals; apart from the control of flood risks, interventions sought the development of networked infrastructures for transportation and navigation and the promotion of agriculture and livelihoods. HUPE points to the collective social stakes in the coproduction of urban deltas through conflicts, negotiations and collaborations across places and periods and at different scales. ${ }^{11}$

This article does not simply juxtapose two case studies but sets them into conversation with each other, using their comparison as a heuristic tool from which each case study is to gain. As comparative scholarship on flood risks and mitigation remains rare, ${ }^{12}$ we take a cue from the fast-growing field of comparative urbanism to bring to the fore shared as well as distinctive processes shaping the urban within dynamics of delta building. Here, we use two

\footnotetext{
9 B. Wisner, P. Blaikie, T. Cannon and I. Davis, At Risk: Natural Hazards, People's Vulnerability and Disasters (London and New York: Routledge, 1994).

${ }^{10} \mathrm{~S}$. Moore, Alternative Routes to the Sustainable City (Lanham: Lexington Books, 2007).

${ }^{11}$ J. Mukherjee, Blue Infrastructures: Natural History, Political Ecology and Urban Development in Kolkata (Singapore: Springer Nature, 2020).

${ }^{12}$ S. Weissenberger, M. Noblet, S. Plante, O. Chouinard, J. Guillemot, M. Aubé, C. Meur-Ferec, et al., 'Changements climatiques, changements du littoral et évolution de la vulnérabilité côtière au fil du temps: Comparaison de territoires français, canadien et sénégalais', VertigO - la revue électronique en sciences de l'environnement 16(3) (2016). J. Guerrin and G. Bouleau, 'Remparts ou menaces? Trajectoires politiques de l'endiguement en France, aux Pays-Bas et aux États-Unis', Revue internationale de politique comparée 21(1) (2014): 89-109.
} 
seemingly very different cities ${ }^{13}$ to apply a "comparative tactic" ${ }^{14}$ that avoids falling back to received and often misleading geographical categories ${ }^{15}$ and that has the potential to contribute to a more global urban environmental history. Such an "unexpected comparison" ${ }^{16}$ helps us to position (delta) cities around the globe within larger environmental and political processes while recognizing their situatedness and distinctiveness, parallelly accomplishing the "grounding" and "worlding" agendas, recently put forward by historians advancing "comparative urban environmentalism". ${ }^{17}$

\section{CASE STUDIES ARLES AND KOLKATA}

\section{Fluid Histories}

\section{Arles: Local Flood Management for a Growing Deltaic Agrocity}

Arles grew as an important city during the Roman times, asserting its regional influence as a commercial hub at the intersection of the two main trade roads in the Languedoc and the Provence. At the head of the Rhône Delta, Arles was furthermore the last city before the Mediterranean Sea and connected to the Upper Rhône Valley through inland navigation. ${ }^{18}$

The city evolved as the regional capital. Since the twelfth century, Arles also gradually expanded as an "agrocity" as the Rhône Delta presented a large reservoir of arable lands, constituting the main economic resource of the Arlesian population. ${ }^{19}$ Wetlands surrounding the city provided natural resources, including fish, reeds for thatching roofs and food crops. In the thirteenth century, Arlesians began to invest in land reclamations, first near the city and later on more distant lands, up to $15 \mathrm{~km}$ from the city. ${ }^{20}$ To secure their investment, Arlesian elites (mostly the nobility and the Church) established specific institutions responsible for

\footnotetext{
${ }^{13}$ Kolkata has a population of 14.38 million people (2011 census) and Arles is inhabited by 53,000 people. They are situated in very different political and economic contexts.

${ }^{14} \mathrm{~J}$. Robinson, 'Thinking cities/the urban through elsewhere: Comparative tactics for a more global urban studies', Progress in Human Geography 40(1) (2015): 3-29.

${ }^{15}$ J. Jacobs, 'Commentary: Comparing comparative urbanisms', Urban Geography 33(6) (2012): 904-14.

${ }^{16}$ G. Myers, 'From expected to unexpected comparisons: Changing the flows of ideas about cities in a postcolonial urban world', Singapore Journal of Tropical Geography 35(1) (2014): 104-118.

${ }^{17}$ H. Ernstson and S. Sörlin (eds), Grounding Urban Natures: Histories and Futures of Urban Ecologies (Cambridge, Massachusetts and London: The MIT Press, 2019).

${ }^{18}$ J. -M. Rouquette, dir, Arles. Histoire, territoire et cultures, Paris, Imprimerie nationale, 2008, p. 179191.

${ }^{19}$ L. Stouff, Arles à la fin du Moyen Âge, (Aix-en-Provence: Université de Provence, 1986).

${ }^{20}$ E. Roucaute, 'Gestion et exploitation du marais arlésien au Moyen Âge', in P. Leveau, J. Burnouf (eds), Fleuves et marais. Une histoire au croisement de la nature et de la culture (Paris: CTHS, 2004), pp. 245252.
} 
maintaining dykes along the Rhône; city officers, the levadiers, were in charge of this task. ${ }^{21}$ However, floods regularly threatened the arable lands. Therefore, it was crucial to delineate parcels in this muddy and unstable environment as to ensure the protection of property.

Agricultural activities in the Rhône Delta became more intensive in the sixteenth century. The delta was owned by the major pars (greater, prominent part) of the Arlesian citizenry. In 1543, some of the most influential and rich citizens of Arles founded the Association of Corrège-Camargue Majour with the support of the local monarchical representative. ${ }^{22}$ The main actors in this organisation belonged to the Arlesian elites. In 1582, nine out of 16 people involved in the Association were nobles, five belonged to Arles' bourgeoisie, and two were members of the clergy. ${ }^{23}$ Their aim was to reclaim a larger portion of the Camargue. The digging of the Corrège Canal initiated the spread of agriculture to the interiors of the delta, which evolved as the regional breadbasket. Building upon the inherited institution of levadiers, the Association pooled financial resources to share the cost of the works required to separate land and water and to develop new arable lands. Despite the French wars of religion, these efforts continued during the second half of the sixteenth century. They accelerated during the seventeenth century with the support of Richelieu and Mazarin, Prime Ministers to the French kings Louis XIII and Louis XIV. The whole delta territory was eventually divided into separate drainage associations, of which the Association CorrègeCamargue Majour remained the most prominent, that regrouped landowners and allowed effective water management, including flood control and irrigation works. Through this process, the delta became established as the hinterland of the city of Arles. ${ }^{24}$

\footnotetext{
${ }^{21}$ Levadiers is a local French word derived from levade (levee).

${ }^{22}$ R. Morera, 'Mise en valeur des zones humides et associations de gestion. Naissance et affirmation de nouveaux pouvoirs territoriaux (France, XVIe-XVIIIe siècles)', Siècles. Cahiers du Centre d'histoire Espaces et Cultures 42 (2016).

23 Archives municipales d'Arles, Délibérations des conseils des corps de la levaderie de Corrège, 11th Feb. 1582. R. Morera, L'assèchement des marais en France au XVIIe siècle (Rennes: Presses Univ. de Rennes, 2011.

24 É. Roucaute, G. Pichard, 'Les cadastres des associations territoriales d'Arles, témoins de la gestion des zones humides au XVII ${ }^{\mathrm{e}}$ siècle', Siècles 30 (2009): 47-60.
} 
Floods remained regular in the Arlesian fluidscape, comprising both the city and its deltaic surroundings. Dykes often collapsed letting freshwater from the closest mountain range inundate arable lands. Historical sources document more than 73 flood events in the eigtheenth century; ${ }^{25}$ these severely affected the drainage associations as the Proceedings of the Corrège Majour Association demonstrate (Box 1). ${ }^{26}$ These Proceedings also show how landowners managed flood risks and recovered their land after massive inundations. In 1756, the members of the Camargue Majour Association quadrupled their actual expenses $(30,805$ livres tournois), compared to 1755 . In 1757 and 1758, the expenses remained at a very high level (twice the amount of 1755) before a drastic decline, indicating the efficiency of the interventions of the Association.

In sum, agriculture in the Rhône Delta required both regular and extraordinary investments in flood management (creation and repair of dykes) for which the Arlesian landowners and their association(s) borrowed money. However, the sediment deposits after each flood also enriched the soil. 27 Over centuries, locallevel institutions in charge of dykes and water technologies played an important role in flood management. The system was largely functional as the landowners cum members of the Association had a monetary incentive to maintain and restore dykes.

\footnotetext{
${ }^{25}$ https: $/$ histrhone.cerege.fr/spip.php?page $=$ tab results $\&$ nbreponse $=73 \&$ crit date $1=1700 \&$ crit date $2=1800$ \&crit_typeevent $=\mathrm{C} 2, \mathrm{C} 3, \mathrm{C} 4, \mathrm{Cd}, \mathrm{Ci} \&$ crit_commune $=$ Arles\&idart_retour=78 $($ accessed 22 Oct. 2020).

${ }^{26}$ Archives municipales d'Arles, Corrège Majour, non-listed document.

27 J. Guerrin, E. Comby, R. Morera, 'From asset to threat: trajectory of sediment on the Rhône River (France)', Water History (forthcoming: 2021).
} 


\section{Kolkata: Land Reclamations for a Growing Deltaic Mercantile City}

The urban history of Kolkata is much more recent than that of Arles. The city grew from a trading post established by the East India Company at the site of three villages along the Hooghly-Bhagirathi River (a sidearm of the Ganga) in the Bengal Delta and on the edge of the Sundarbans, the world's largest mangrove estuary. Kolkata's tidal roots are evident in the traces of anthropogenic canals and the numerous ghats (banks) along the river depicted in medieval Bengali literature. ${ }^{28}$ Its name literally means a shore (kol) cut open (kata) (by creeks and inlets). ${ }^{29}$ Numerous place names within today's city (e.g., Creek Row or Ultadanga, meaning 'dry land close to the river') indicate the city's marshy past. Furthermore, a small collection of songs, couplets and artisanal paintings from early inhabitants (fishers and falconers) of the saline marshes attests to the city's long-forgotten watery origins. ${ }^{30}$ At the eastern periphery of Kolkata, vast marshes formed at the intersections of meandering streams, rivers carrying freshwater from the Gangetic plains and saline water influxes from the sea. Brackish water came mainly from the tidal river Bidyadhari that brought water from the Bay of Bengal and spilled it into this undulating, lowlying area, leading to the formation of salt-water lakes.

When the British colonizers encountered this fluid deltascape, they castigated the area as "unhygienic", "wild" and "inhospitable". ${ }^{31}$ In 1667, the East India Company appointed Joseph Townshend as the "Pilot of the Ganges" to carry out first surveys of the riverfront taking detailed notes on the river's depths, reaches, currents, sand variation patterns, etc. Based on these measurements, the Company chose to establish a fortified trading post at the site of today's Kolkata in 1690. The estuarine geomorphology of the site of Kolkata - where the delta is interspersed by numerous distributaries of the Ganga, channels, creeks, inlets and

\footnotetext{
${ }^{28}$ For example, Bipradas Piplai's Manasa Mangal Kavya or Kavikankan Mukundaram's Chandi Mangal Kavya.

${ }^{29}$ O. Biswas, Calcutta and Calcuttans: From Dihi to Megalopolis (Calcutta: KLM Firma, 1992).

30 D. Bhattacharyya, Empire and Ecology in the Bengal Delta: The Making of Calcutta. (Cambridge: Cambridge University Press, 2018).

${ }^{31}$ J. Martin, Notes on the Medical Topography: Report of the Committee Appointed by the Right Honourable the Governor of Bengal for the Establishment of a Fever Hospital and for Inquiry into Local Management and Taxation in Calcutta (London: G.H. Huttmann, 1836). F. Strong, Extracts from the Topography and Vital Statistics of Calcutta (Calcutta: Sanders, Comes \& Co., 1837). C.R. Wilson, The Early Annals of the English in Bengal. London: W. Thacker \& Co, 1895).
} 
salt-water marshes - offered multiple locational and hydrological advantages for the British entrepreneurs that outweighed its inherent risks of the area. ${ }^{32}$

In the first half of the eighteenth century, Kolkata grew as a trading post and export centre for textiles (silk). For its urban development, the East India Company needed to reclaim marshlands further and further east from the Hugli River. However, the focus remained on trade and navigation; agriculture and revenue collection in the deltascape near Kolkata were left to the zamindars (landlords) under the control of the Nawab (Mughal ruler). It is therefore not surprising that the colonial archives largely remain silent on deltaic agriculture during this time. ${ }^{33}$ Only by 1930 , William Willcocks, a colonial engineer who directed the construction of some of the largest hydrological dams at the time, (re-)discovered the merits of what he called "overflow irrigation" traditionally practised in the Bengal delta. In this ageold practice, nutrient-rich, silt-laden monsoon floodwaters were distributed evenly over plots in the delta to irrigate and fertilize the fields. Floodwater was directed through a system of wide, shallow canals along small embankments (locally known as bunds); local breaches were made in the bunds to irrigate or drain particular fields at the appropriate time. This system was able to prevent floods by using agricultural fields as water receptacle. It also enabled pisciculture, which reduced mosquito populations and thus malaria. Village-level water boards, working in collaboration with farmers and fishers, were in charge of the systematic distribution of floodwater. ${ }^{34}$ Similar to the Rhône Delta, therefore, floods in Bengal were perceived as blessings and managed by local institutions.

\section{Imperial land-water separations}

\section{Disconnecting Arles from the Rhône Delta: Interventions by the French State and the}

\section{Rise of Industrial Interests}

Draining the Camargue remained an important goal of the emerging central political power throughout the nineteenth century. In the following years, new actors appeared on the scene,

\footnotetext{
32 J. Mukherjee, 'The victory of site over situation: Exploring ecological dynamics behind Calcutta's selection as the seat of colonial capital', Quarterly Review of Historical Studies 49(3-4): 40-55.

${ }^{33}$ Other archives, including oral histories, do not provide sufficient, conclusive information on overflow irrigation either.

${ }^{34}$ W. Willcocks, Lectures on the Ancient System of Irrigation in Bengal (Calcutta: University of Calcutta, 1930); D. Klingensmith, One Valley and a Thousand: Dams, Nationalism, and Development (New Delhi: Oxford University Press, 2007). J. Mukherjee, 'From hydrology to hydrosociality: Historiography of waters in India', in J. Caradonna (ed.), Routledge Handbook of the History of Sustainability (London: Routledge, 2018).
} 
including investors in 1802. ${ }^{35}$ During the First Empire (1804-1814), following the unstable period of the French Revolution, Napoleon I renewed the legal framework encouraging investment in land reclamations and agriculture. In 1805, Napoleon promulgated a decree concerning the whole Camargue. ${ }^{36}$ Noting the general collapse of the drainage infrastructure, the decree established the imperial economic principles in the region. In particular, it imposed a poll tax on the landowners and created a new local organization supervising collective decision-making in water management. Known as the Central Committee, it gathered the representatives from the Arlesian elites. The decree also ordered centralised supervision, through the role of the préfet (prefect), the State representative in the département (county), with the aim of facilitating collaboration between local landowners and institutional actors. These institutional arrangements were consolidated in the law of 1807. ${ }^{37}$ Arles' bottom-up water management prior to the French Revolution transformed into a State-controlled project during the beginning of the nineteenth century. Thenceforth the inland navigation agenda emerged to promote the regional development of the Camargue. In 1817, following extensive surveys, F. Poulle, a young engineer from the Ponts et Chaussées administration, proposed the excavation of a navigable canal on the left bank of the Rhône also to drain the area and reclaim more land. This project was sanctioned by the local landowners and the King in 1827 and implemented in 1834 and the following years. ${ }^{38}$

The 1856 flood affected the Camargue severely, causing massive loss of crops and cattle. After Napoleon III visited the affected Rhône Valley, an integrated vision for river management was formulated in 1857 to prevent such events in the future. ${ }^{39}$ Subsequently, State engineers designed water infrastructures leading to the large-scale colonization of the Camargue. Napoleon III urged the building of a massive dyke at the coast to prevent the intrusion of seawater into the Camargue. The French State met the requests of the Arlesian landowners who sought to protect their lands to augment agricultural production. In turn, the

\footnotetext{
${ }^{35}$ Demande de la compagnie Decroy en concession de l'assèchement des marais d'Arles, 14 ventôse an 13, 5 March 1805, Délibération de l'association du desséchement des marais d'Arles (Arles: Adolphe Mesnier, 1827), p. 383 and sq.

${ }^{36}$ Décret du 4 prairial an XIII, Délibération de l'association du desséchement, pp. 423-436.

${ }^{37}$ Loi relative au desséchement des marais, 16-26 Septembre 1807, in Collection complète des lois, décrets, ordonnances, règlements et avis du Conseil d'État, Tome XVI, (Paris, 1826) : 193-201.

38 Délibération de l'association du dessèchement des marais d'Arles, 4 March 1827, Délibération de l'association $d u$ desséchement, IX-LXXII. Ordonnance du roi, St-Cloud, 29 May 1827, Délibération de l'association $d u$ desséchement: LXXIII-LXXVI.

39 Annie Méjean, 'Utilisation politique d'une catastrophe: le voyage de Napoléon III en Provence durant la grande crue de 1856', Revue historique 597 (1996): 133-151.
} 
landowners had to take responsibility for the maintenance of the dykes by re-creating the water management association, henceforth called Syndicat de gestion des chaussées de Grande Camargue. The State also provided financial support pertaining to one-third of the total investment.

While the State continued to promote agricultural development, it also facilitated the establishment of actors from outside the delta, cutting the link between the city of Arles and the Rhône Delta. ${ }^{40}$ Industrial ambitions accelerated this evolution. The Rhône Delta was gradually transformed into an extractive space. Under the Second Empire (1851-1870), the regular business of salt production under the aegis of the French State made way to more profitable chemical industries. In 1789, the Leblanc mechanism of soda ash manufacturing turned to be lucrative for steel industry. ${ }^{41}$ The Compagnie des Salins du Midi was created in 1856 to facilitate business in the Arlesian territory. Salt extraction and soda ash production were supported by the State administration through extensive surveys. The Canal from Arles to Port-de-Bouc linked the area to upstream to Lyon through inland navigation. ${ }^{42}$ However, these transformations entailed social conflicts in the Camargue, triggered by clashing interests among actors. While farmers sought the fast draining of freshwater to the sea, industrialists wanted the penetration of seawater to feed their large salt-making fields. The dispute culminated in a trial in 1892 and the court attempted a compromise satisfying both farming and industrial lobbies. ${ }^{43}$ The sea dyke was built to protect lands and the industry was compensated for their loss. Moreover, a new railway, joining Arles and the newly created industrial town of Salin-de-Giraud was built in 1892. A new plant was set up for salt extraction in Salin-de-Giraud in 1895, financed by the Solvay industrial company - a strategic development for the national metallurgic industry. ${ }^{44}$

The shift towards industrial economy drastically transformed the relations between Arles and the delta, since it no longer belonged exclusively to the city. In the northern part of the delta,

40 Enquête sur le projet d'amélioration de la Camargue présentée par la société lyonnaise d'études (Marseille : Imprimerie Marseillaise, 1898), p. 20.

${ }^{41}$ T. Le Roux, Le laboratoire des pollutions industrielles. Paris, 1770-1830 (Paris: Albin Michel, 2011): 251-252.

42 Enquête sur les sels (Paris: Imprimerie Impériale, 1868), Tome II, p. 48.

${ }^{43}$ Sigolène Pailhès, 'La digue à la mer ou les mésaventures de l'État en Camargue. Contribution à l'histoire sociale à travers l'histoire de l'aménagement de la basse Camargue dans la seconde moitié du XIXe siècle', Provence historique 200 (2000): 189-206.

44 X. Daumalin, O. Lambert, P. Mioche, Une aventure industrielle en Camargue: Histoire de l'établissement Solvay de Salin-de-Giraud: 1895 à nos jours (Aix-en-Provence, REF2-C, 2012). 
agrarian interests remained very strong. But the economic evolution cut the link between Arles and its larger ecological infrastructures.

Furthermore, the Camargue was indirectly affected by intensified French colonialism during the nineteenth century. The subjugation of Algeria in the $1830 \mathrm{~s}$, the penetration to parts of Sub-Saharan Africa and Asia by the end of the nineteenth century and the opening of the Suez Canal in 1869 reinforced Marseille as the primary city in Southern France and the primary port expediting colonial trade. The position of Marseille vis-a-vis Arles was further strengthened through the development of railways linking Marseille to Paris and Lyon. In that context, Arles could no longer assert its economic importance, neither as a fluvial trading centre nor as a strategic breadbasket. As a matter of fact, the delta was ruled by higher interest.

\section{Reconnecting Kolkata to the Delta: Colonial Trade, Land Taxes and Sewage Treatment}

After gaining the right to collect taxes on behalf of the Mughal Court in the mid-1700s, the British colonialists intensified their efforts to control the Bengal Delta. Extensive land and water surveys were conducted ${ }^{45}$ that provided the base for the colonial systems of revenue generation from land. Eventually, the Permanent Settlement Act of 1793 introduced a fixedrent regime in Bengal that also created the land-water binary in the delta. ${ }^{46}$ The new imperialist property regime, transforming the zamindars from mere tax collectors to landlords, together with progress in tropical botany and the transfer of useful plants from Kolkata's Botanical Gardens (est. 1786), were supposed to give an impetus for agricultural development in Bengal. ${ }^{47}$ This attempt largely failed. However, the colonizers - to whom the principles of "modern" hydrology, too, were known by this time - plunged into the venture of transforming the deltascape into a manufactured space as they foresaw the economic logic of commercial development of the Bengal Delta. While the role of the Hooghly River as the global gateway to and from the Ganga Delta was reinforced, an intricate network of canals was created and maintained between 1770s and 1910 leading to 'the efflorescence of port

\footnotetext{
45 These included the land survey by Robert Barker, the statistical survey of landholdings by William Farkland, river surveys by Thomas Bowrey, a nautical survey by Captain John Ritchie between 1767 and 1770 and entrepreneur Benjamin Lacam, and cartographic experiments (1763-1777) by Major-General James Rennell.

${ }^{46}$ R. D'Souza, 'River as resource and land to own: The great hydraulic transition in Eastern India', Asian Environments Shaping the World: Conceptions of Nature and Environmental Practices. Singapore, 2009.

${ }^{47}$ D. Arnold, 'Agriculture and 'improvement' in early colonial India: A pre-history of development. Journal of Agrarian Change 5(4) (2005): 505-525.
} 
cities as viable commercial centers of trade and transportation.' ${ }^{48}$ In this scenario, soaked and muddy lands were considered unproductive as these disrupted the colonial calculus of rule of fixed property and flowing (navigable) waters.

In particular, the Eastern Canal System, cutting over more than $300 \mathrm{~km}$ through the delta, opened a navigation route between Kolkata and eastern Bengal. ${ }^{49}$ A network of canals was created between the rivers Hooghly (to the west) and Bidyadhari (to the east) and stretching downstream to the Meghna Estuary. The scheme involved numerous river improvement projects and dredging operations carried out by the Port Commission and the Irrigation and Waterways Department (IWD) between 1770s and 1910. Artificial canals were dug to connect the tidal channels and rivers of the Sundarbans to this waterway. According to records maintained by the British executive engineers, Kolkata's canal system had few competitors in the world at the time in terms of the bulk of goods it transported. ${ }^{50}$ The Eastern Canal System connected Kolkata with its hinterland, catering to the needs of the expanding city in terms of trade and transportation.

In the process, the small, flexible bunds underpinning traditional overflow irrigation were replaced by larger, fixed embankments. The Embankment Act of 1855 brought both public and private dykes under state control; for instance, it was forbidden to cut through any embankment without state permission. As a consequence, lands were insulated from inundation, irrigation and fertilization. At the same time, traditional drainage networks were destroyed so that low-lying areas often became waterlogged. Silt and nutrient deposits were no longer dispersed over the flood plain, but they accumulated in riverbeds. In sum, the British - who failed to understand the multiple functions offered by age-old overflow irrigation and who turned the delta into easily taxable land (property) interspersed with navigable waterways - transformed the delta from a flood-dependent agrarian regime into a flood-hazard landscape. ${ }^{51}$

\footnotetext{
48 J. Mukherjee, Blue Infrastructures, p. 55.

49 W. Inglis, The Canals and Flood Banks of Bengal (Bengal: Bengal Secretariat Press, 1909). L.S.S. O’Malley, Bengal District Gazetteers: 24 Parganas (Calcutta: Bengal Secretariat Book Depot, 1914).

${ }^{50} \mathrm{H}$. Bandopadhyay, History of Canals in Bengal (Kolkata: Doshor Publication, 2018) and J. Mukherjee, Blue Infrastructures have extracted trade and revenue collection data from colonial archive, demonstrating the significance of Kolkata's canal network.

${ }^{51}$ R. D'Souza, 'Colonialism, capitalism and nature: Debating the origins of Mahanadi Delta's hydraulic crisis (1803-1928)', Economic and Political Weekly 37(13) (2002): 1261-1272.
} 
Closer to the city of Kolkata, the deltascape also provided affordable urban utilities, particularly in terms of drainage, sewerage, sanitation and food. Starting in the 1860 s, saltwater lakes were embanked and wetlands were used for sewage farming and fishing. Experiments to produce rice, vegetables, cotton and cattle fodder in sewage farms were carried out in 1868-1869 by the then Health Officer Fabre Tonnerre. ${ }^{52}$ Oral histories attest that the fishers and the zamindars paid taxes to the Department of Fisheries, Government of Bengal, for carrying out these activities. In 1865, the Salt Water Lakes Reclamation and Irrigation Company Limited was established. Lands reclaimed by the Company in Dhapa (the city's dumping yard) in 1865 were leased out for an annual rent. The lessee successfully cultivated maize, aubergine, cauliflower and corn; data on the annual rent collected shows that cess collection progressively increased over the years. ${ }^{53}$

Between the 1880s and the first half of the twentieth century, clashing priorities and interests between navigation needs and urban drainage-sewerage-sanitation requirements appeared prominently in colonial records of the Military Board, the Kolkata Municipal Corporation (KMC), the IWD and the Public Works Department (PWD). The role of particular canals, as arteries of trade or receptacles of Kolkata's wastewater, was highly debated among different branches of the government, as was the function of marshes, to be reclaimed for urban development or to be preserved due to their importance as an urban outfall. A series of plans, proposals, schemes and designs were formulated, debated, annulled or implemented to address traffic needs, tidal accumulations and sewage issues. The State of Bengal had to navigate between interests for the flow of traffic and the flow of effluents through the canals; the $\mathrm{KMC}$, for example, would have preferred to preserve the Eastern Canal System for navigational purposes and to build new drains to transport the city's sewage and storm water.

In 1928, the city's drainage faced a deadlock when the Bidyadhari River, which had served as the main outfall channel, was officially declared to be "dead" due to natural and man-made

\footnotetext{
${ }^{52}$ The colonizers were interested to harness benefits from cultivation in the salt water lakes which is evident from their mindset - 'even if nothing else but mere guinea-grass were grown, the returns would be such as to secure shareholders a fair percentage on the invested capital' (quoted in W. Inglis, The Canals and Flood Banks of Bengal, p. 259).

${ }^{53}$ H. Chattopadhyay, From Marsh to Township East of Kolkata: A Tale of Fresh Water Lake and Salt Lake Township (Kolkata: K.P. Bagchi \& Company, 1990).
} 
reasons. The Kulti River was selected as the alternative outfall. ${ }^{54}$ Within the project, two parallel channels: the dry weather flow (DWF) and the storm water flow (SWF) stretching from Bantala to Kulti (17 miles) were excavated. Huge sedimentation tanks were constructed by the KMC in 1945 to conduct experiments to confirm that the effluent being carried by the DWF Canal was free from suspended solids to the extent of 85 percent (Calcutta Corporation, 1946). A series of properly designed arterial feeding and inlet drainage channels were excavated that connected to the DWF, which carried wastewater to the fisheries (bheris in the local Bengali dialect). The new outfall scheme and the entire design paved the way to sewage-fed fisheries based on wise-use resource recovery practices - a collective endeavour by the government, the zamindars and the fishers. These sewage-fed wetlands came to be designated as the "East Kolkata Wetlands" (EKW), located within the larger deltaic (saltwater) marshes dispersed between Kolkata and the Sundarbans. ${ }^{55}$

Using nature's services (sunshine, algae, coliform bacteria, water hyacinths), wastewater came to be recycled in EKW through a series of waste stabilization ponds - excavated by locals - that were connected to the inlet canals drawing city's wastewater from the primary DWF Canal. Effluents, flowing through locally designed and implemented low-cost folk technology (including pond preparation, primary fertilization, fish stocking, secondary fertilization, and fish harvesting, etc.) were treated naturally.

In both Kolkata and Arles, the (colonial) state increasingly shaped, altered and artificialized the deltascape during the nineteenth and the beginning of the twentieth century and superseded local land-use practices and institutions. With the arrival of new actors and interest groups, the city of Arles became gradually disconnected from its delta while Kolkata intensified the links with its hinterland through commerce and with its periphery through

\footnotetext{
${ }^{54}$ From Corporation reports, it is evident that due to the non-enforcement of an Embankment Act between Dhapa and the mouth of the River due to strong protests from the zamindars (landlords), the river faced challenges. While the farmers were keen to utilize the marshes as rice fields, the fish owners formed bheris (fishponds) by erecting embankments to prevent the spill waters of the Bidyadhari. This caused obstruction to the spilling of the waves by the tidal river in the natural spill basin leading to the deposition of huge amounts of silt carried on the riverbed, making her moribund.

${ }^{55}$ When the Bidyadhari River was replaced by the Kulti River as the outfall channel, joined by the DWF and SWF carrying municipal wastewater, the saline water not enter and get accumulated in the marshes leading to a change in the aquatic regime from saline-fed to sewage-fed fisheries. The nomenclature "East Kolkata Wetlands" owes to the ecological engineer and former Chief Environmental Officer, Government of West Bengal Dr Dhrubajyoti Ghosh who first delineated and documented the wise-use, low-cost folk technology pursued by the fishers using municipal wastewater.
} 
wastewater recycling. Toward the end of this period, the state also seems to play a growing role in mediating between groups with different interests in the deltascape.

\section{Contemporary Conjunctures}

\section{Arles and the Delta: New Forms of River and Flood Management}

In the twentieth century and particularly after World War II, the Rhône and flood risks were conceived in a new way. Interest emerged in damming the Rhône for hydroelectrical power generation. While they can be traced back to the last decade of the nineteenth century, Parisians made concrete attempts in 1917 to obtain a concession for building the Génissiat Dam about $50 \mathrm{~km}$ upstream from Lyon and $250 \mathrm{~km}$ from Arles with the goal of generating energy for the capital. However, this was opposed by diverging regional interests and powers within the Rhône Valley - those favouring the development of the river for international navigation and those of farmers who wanted to use the Rhône for irrigation. Subsequently, the French state established the Rhône National Company (CNR) in 1933 with the purpose of mediating between the differing interests and developing hydroelectricity production, navigation and irrigation at the same time. This history explains the emergence of the CNR as a mixed-economy society after World War II through which Parisian interests (of both the central state and industrialists), local powers, and national industry (French national public company and national railways) would share the costs and benefits of the "development" of the Rhône. 56

The Rhône was channelized through major dykes from the Swiss border to the mouth of the delta. Between 1945 and 1986, CNR built 19 hydropower dams along the river. During the 1970s and 1980s, five nuclear plants were built near the Rhône, drawing water from the river canal to cool the reactors. However, the benefits from these major works, which transformed the former wild Rhône into a domesticated canal, barely reached the delta and Arles. Arles remained excluded from the development of the valley through nuclear and hydropower development (except for some benefits from the construction of an industrial platform and from dredging works). Yet, its hydraulic regime was profoundly altered. Even before this industrial development, an environmental conservation movement rose in the Camargue. In 1927, for example, the National Society for Nature Protection created a 13,000-hectara nature

\footnotetext{
${ }^{56}$ A. Giandou, La compagnie nationale du Rhône (1933-1988). Histoire d'un partenaire Régional de l'État (Grenoble: Presses universitaires de Grenoble, 1999).
} 
reserve that was managed by local actors. Later in the 1970 s, the 85,000 ha Camargue Regional Natural Park was established with aim to reconcile local economic activities and environmental protection. ${ }^{57}$

In 1993 and 1994, several dyke breaches resulted in the flooding of 23,500 ha of the Camargue incurring costs of 30 million euros. The artificialized delta and deficient maintenance of the dykes increased both the intensity and the duration of flooding. The landowners were blamed for the lack of maintenance of the dykes raised after the 1856 flood, and individual farmers were accused of weakening the dykes by drilling informal tunnels to irrigate their lands directly from the Rhône. The Syndicat was reproached for improper financial management. ${ }^{58}$ In turn, the landowners' Syndicat pointed the finger at the tourism and salt industries and sought funding for flood protection from these sectors. Neo-rural Camargue inhabitants living near the dykes were particularly affected by the damages and led a battle against farmers.

These flood events transformed the nature of flood management in the Camargue from a community-based to a (local) public maintenance regime. In 1996, an association of three municipalities - Arles, Port Saint-Louis and Saintes-Maries-de-la-Mer - was formed to rebuild and maintain the Camargue dykes. The Region and the Department (two sub-national levels of government in France) joined the three municipalities in 1999 to form a new intergovernmental institution, the SYMADREM. Some engineers, mandated by the State to conduct assessments, advocated for the reopening of the delta to flood-water storage by lowering the dykes. However, the State's own engineers judged this suggestion as "socially unacceptable" and economically unrealistic. ${ }^{59}$ Eventually, a compromise was made: the dykes surrounding urbanized areas were strengthened but the river was allowed uninterrupted flow through some arable lands during floods.

The subsequent 2003 flood, caused by a dyke breach upstream, hit the city of Arles harder than the delta, which was relatively well protected thanks to the SYMADREM interventions.

\footnotetext{
${ }^{57}$ R. Mathevet, Camargue Incertaine (Paris: Buchet Chastel, 2004): 112-115.

58 B. Picon, P. Allard, C. Claeys-Mekdade, S. Killian. Gestion du risque inondation et changement social dans le delta du Rhône. Les catastrophes de 1856 et 1993-1994 (Paris: Cemagref, 2006).

${ }^{59}$ P. Balland, C. Lefrou, Rapport sur la gestion de l'eau en Camargue. La protection contre les inondations, (Paris: Conseil général des ponts et Chaussées, 1999).
} 
The flood affected socially vulnerable inhabitants of Trébon, located north of Arles, badly. The event provoked a stronger involvement of the State in flood management and governance. The State created the Plan Rhône in 2007 through a strategic and financial collaboration with regional authorities, the CNR, and the European Union. Plan Rhone also brought together several departments and key municipal authorities located along the Rhône in its steering committee; local inhabitants and associations were included in the newly formed consultative committees. The Plan Rhone partnership was allowed to grant funds to local governments, project managers and inhabitants intending to implement projects in tune to its overall agenda of mitigating flood risks. It financed major works related to reinforcing and raising dykes to protect urban and industrial areas. Dykes became more resilient to overflooding and the bed of the Rhône was enlarged in parts in order to protect Arlesians. Works under the Plan Rhône are still being implemented by the SYMADREM.

In sum, flood protection in the Camargue delta was profoundly reorganized in the $20^{\text {th }}$ century. From a system facilitating navigation and protecting agricultural and industrial land through local professional associations, flood management was transferred to local authorities and financially supported by the State. Today, the deltascape is managed with the goal to accommodate pre-existing landed and industrial interests with the protection of local urban habitats.

\section{Kolkata: Degradation, 'Development' and Displacement}

When transportation technologies shifted from steam navigation to the railways at the onset of the twentieth century, Kolkata's canal network began to degrade to a mere conduit of wastewater. ${ }^{60}$ The railways became in itself a powerful institution. For example, the Bengal government legislation allowed the lieutenant governor to order the blocking of any navigable channel. Consequently, the railway lines and embankments disrupted Bengal's canal system and what was left of its traditional overflow irrigation system.

${ }^{60}$ A. Mitra, Census 1951. West Bengal District Handbook-24 Parganas (West Bengal: West Bengal Government Press, 1954). 
Kolkata's canal network deteriorated even further in the post-colonial period; i.e., since the 1950s. In the 21st century, furthermore, the entire Eastern Canal System, the primary municipal DWF canal, as well as the secondary and tertiary inlet canals carrying wastewater to the bheris, are threatened by lack of proper maintenance leading to siltation and by rampant wetland conversions and building developments generating massive socio-ecological costs. For example, the connection between the Adi Ganga-Tolly's Canal to Kolkata's Eastern Canal System has been disrupted by the city's metro project (Box 2). The Beleghata Canal has lost its environmental flow regime and the squatters inhabiting its bank were displaced when the Canal West Road was expanded. These processes in the urban deltascape represent a nexus of degradation, 'development' and displacement.

Concurrently, 12,500 hectares of the EKW were declared as a Ramsar site in 2002. This area comprises 254 bheris and recycles 750 million litres of effluents, generating 22 tonnes of fish and 150 tonnes of vegetables per day through the application of wise-use resource recovery practices pursued by wetland dwellers. Today, the EKW ensures livelihoods of about 100,000 people. Nevertheless, this space of great socio-ecological significance is dwindling in size, resulting into diminishing flows of ecosystem services. Dhrubajyoti Ghosh's remark about the EKW as "real estate in waiting" is a vivid projection of the past, present, and future of wetland conversion, capturing the phenomenal rise of "consumption cities" within the context of rapid "urban sprawl" in Asia. ${ }^{61}$ A series of new townships and urban development projects have converted the wetlands into estate, epitomizing 'a saga of

\section{Box 2: Demise of the Tolly's Canal}

When the Kolkata metro railway extension project was built in 2002 leading over the canal from Tollygunge to Garia, 300 pillars, each at a distance of $20 \mathrm{~m}$ from the next, were dug into the canal bed (Mukherjee 2016). The project was sanctioned in spite of protests, petitions, and litigations from different rungs of society and in spite of violation of the Environmental Protection Act (EPA), 1986, and Environmental Impact Assessment (EIA) Notification, 1994. No environmental clearance was sought by the railway authorities. The archaic Section 11 of the Railways Act, 1989, a remnant of the colonial revised edition of the act of 1890 empowered the railways to construct, 'upon, across, under or over any land, any rivers, canals, brooks, streams or other waters." "The outcome was the transformation of our heritage river into a pillar-ridden sewer.'

Source : J. Mukherjee, Blue Infrastructures, p. 140 space, capital and people in the

${ }^{61}$ Dr Dhrubajyoti Ghosh was the sanitation engineer who recognized the immense significance of the EKW as "keystone ecosystem" and played a major role in drawing international attention for wetland protection. Even the nomenclature "EKW" is owed to him. 
vortex of globalised time.' 62 Salt Lake City (1960s), satellite townships such as Baishnabghata Patuli and East Calcutta Township (1970s) and the New Town Rajarhat (1990s) along with the implementation of numerous other development projects have engulfed the wetlands, affecting the survival provisions of marginalized populations.

The degradation and disruption of the drainage-sewerage network has had profound impact on this delta city in terms of increasing vulnerability and decreasing resilience to floods and prolonged waterlogging, nowadays occurring even after only a few hours of rainfall. A recent study has pointed out that the only remaining flood relief provision in the metropolitan area are the Adi-Ganga - Tolly's Nullah stretch and the EKW. The study estimates that between 2005 and $2015,53 \%$ of the eastern wetlands and $86 \%$ of the Tolly's Nullah stretch (dissected by metro pillars) have flows below the average environmental flow volume, disrupting the flood-resilience efficacy of the city and her wetlands by $65 \% .{ }^{63}$ Moreover, the newly constructed residential and commercial high rises on eastern Kolkata bypass depend on groundwater for utilities, exacerbating the risk of land subsidence for this delta city.

Within the contested landscape of the Kolkata wetlands, different exigencies shape contemporary decision-making impacting the fate of ecological resources and ecosystemdependent communities. For example, the EKW is presently facing a crisis in terms of the distribution of wastewater and due to questions of safety relating to consumption of fish produced from effluents. The media has projected deficient wastewater distribution in bheris as a deliberate statist attempt to stifle fisheries. The mainstream narrative centres round the hierarchical positioning between the State (with municipal and irrigation officials having total control of the effluent discharge and disposal mechanism through the operation of pumping stations, lock gates, sluices, etc.) and the fishers (at the receiving end, with no decisionmaking power and influence). However, ethnographical research conducted in numerous bheris, as well as key informant interviews with irrigation engineers, municipal officials and fishers, suggest the presence of a range of clashing priorities and political compulsions, but also of overlapping interests among otherwise divergent sets of actors. The IWD keeps open the regulator gate during the monsoons to lower the wastewater level in the main canal: This

${ }^{62}$ I. Dey, R. Samaddar and S. Sen, Beyond Kolkata: Rajarhat and the Dystopia of Urban Imagination (London: Routledge, 2013).

${ }^{63}$ S. Chakraborti, East Kolkata Wetlands only hope for flood-prone Kolkata: Study, Times News Network, 5 March 2017. https://timesofindia.indiatimes.com/city/kolkata/east-kolkata-wetlands-only-hope-for-floodprone-kolkata-study/articleshow/57472932.cms (accessed 22 Oct. 2020). 
prevents flooding in the city, as per demand of the City Corporation. As a consequence, fishers complain about inadequate flows in feeder canals. The IWD thus finds itself in a dilemma between the pressing needs of the Corporation, on one hand, and the fishers, on the other hand. Rather than simply following the priorities of the more powerful, however, regular stakeholder meetings and discussions are held to ensure that the varied needs and interests of the agencies involved in Kolkata's drainage-sewerage-aquaculture enterprise are met. Under the Asian Development Bank funded Kolkata Environment Improvement Project (KEIP) launched in 2002, for example, major portions of the distribution channels have been reclaimed and six sluice gates and nine culverts have been built in close consultation with the stakeholders. ${ }^{64}$ Local fishers have been enthusiastic and appreciative of the measure, arguing that government funding and support have boosted their confidence to pursue wastewater fisheries in EKW.

Kolkata experiences waves of environmental activism surrounding the preservation and restoration of the Adi Ganga and the EKW. The nature of these protests, which involve multiple - sometimes opposing, negotiating and mediating - actors, complicates the powerfocused political ecology perspective. They reflect multiple motives and intentions related to the deltacape - ranging from heritage conservation, the protection of ecosystem services for the city, the conservation of resources for marginalized ecosystem-dependent communities, to concerns with social justice and human rights. This multifaceted urban environmentalism raises at least some challenge to the dominant real-estate drive affecting Kolkata's eastern periphery.

In both Kolkata and Arles, an increasingly diverse set of actors have shaped the deltascape in recent times. A reinforced but changed role of the state has increasingly mediated between diverging and overlapping interest, thus reconfiguring the management of flood risks.

\section{CONCLUSION}

Using historical urban political ecology (HUPE) to trace the environmental histories of deltaic Arles and Kolkata, we have shown why and how floods are strongly dependent on territorial as well as historicized dynamics and negotiations. Looking back in history, we

${ }^{64}$ KEIP (Kolkata Environment Improvement Project), Kolkata Environment Improvement Project (20022013), final report (Kolkata: Kolkata Environment Improvement Project, 2012). 
have demonstrated how the Rhône and the lower Ganga have been built as important axes of trade and inland navigation, shaping the fate and future of Arles and Kolkata respectively. Both deltas were equipped with and transformed through water infrastructures and institutions aiming at developing "modern" agriculture. This, in turn, has led to a change in the perception of floods - from a blessing to a threat. With commercial, industrial and urban developments during the nineteenth century, new actors and divergent sets of economic calculations shaped urban deltaic dynamics and altered flood risks (reducing the frequency of inundations but leading to more extreme flood events). During the twentieth and twenty-first century, conservation initiatives and flood risk management programs emerged but had different impact in the two urban deltascapes. In the Rhône delta, multilevel governance systems were established to meet the challenge of striking a balance between national and local interests, risk management and resource uses. In the Bengal delta, stakeholder consultations take place too; however, these processes are surpassed by urban development that disrupts the drainage canal network of Kolkata, leading to increased flood risks.

Our comparative methodology allowed us to identify these commonalities and specificities. It also made us aware of connections at international scales, beyond the north-south binary. Arles and Kolkata are "less different" than we initially thought and both are imbedded in global processes. Thanks to the comparison with Kolkata where the colonial impact is evident, for example, we realized that the national and international political-economic dynamics that disconnected Arles from its delta in the nineteenth century were largely responsible for drastic changes in water and flood management in the Camargue. The case study on Arles pinpointing to a mediating role of the state, in turn, encouraged us to nuance the analysis of the (post)colonial state and to recognize its role in negotiating between different interest groups.

While our empirical findings inform that flood vulnerabilities in both these deltaic contexts originated in a series of statist interventions that manipulated and tried to "fix" the fluid deltascapes, our case studies also reveal that the deltas were not merely shaped by top-down statist interventions, on the one hand, and disruptive local resistance, on the other hand. Rather, the nuanced narratives point to varied sets of socio-technical flood adaptation responses, imbricated in numerous stories of conflicts, compulsions and collaborations among multiple stakeholders - the state, industrial lobbies, railway lobbies, farmers, fishers, 
landowners and other local elite groups, municipal corporations and different organizations and associations.

Through the Arles-Kolkata comparison, we advance why vulnerabilities and risks like floods should be understood as a dynamic condition, varying in impact over time and through space according to context and beyond the alleged divide between the global North and the global South. ${ }^{65}$ We also assert that the relationship between vulnerability (negative scenario) and resilience (positive scenario) is not straightjacketed as projected by emerging global disaster and resilience/climate change scholarship. ${ }^{66}$ Vulnerability and resilience are partly produced by legacies that history can unveil in order to explain current situations and ultimately reactivate local memories of disasters. Our case studies indicate that in spite of exposure to environmental risks, delta cities are imbued with flood-efficacy. The long history of human settlement in deltas and the omnipresence of muddy waters are also a favouring factor for the (re)activation of memories of both being confronted with floods and coping with them. Finally, our temporal analysis can be considered as a "sediment approach": the contemporary conjectures of our deltascapes represent the topmost strata of the sediments, followed by multiple layers of eventualities across changing politicized temporalities.

${ }^{65}$ J.C. Gaillard, B. Wisner, D. Benouar, T. Cannon, L.C. Cazenave, J. Dekens et al., 'Alternatives for Sustained Disaster Risk Reduction', Human Geography 3(1) (2010): 66-88.

${ }^{66}$ Some factors can be considered as increasing vulnerability and resilience at the same time. Some structural equipment, such as dykes/levees, aimed at lowering exposure and decrease associated vulnerability, can actually decrease resilience of populations (since dykes can impede the memory of floods, increase settlements in floodplains without crisis preparation, and impede the capacity to react in case of dyke failure with particular high peak flows). 